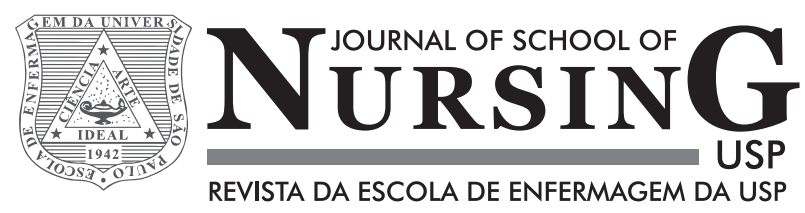

\title{
Effects of auriculotherapy on labour pain: a randomized clinical trial*
}

\author{
Efeitos da auriculoterapia sobre a dor do trabalho de parto: ensaio clínico randomizado \\ Efectos de la auriculoterapia sobre el dolor del trabajo de parto: ensayo clínico aleatorizado
}

\author{
Reginaldo Roque Mafetoni ${ }^{1}$, Antonieta Keiko Kakuda Shimo ${ }^{1}$
}

\author{
How to cite this article: \\ Mafetoni RR, Shimo AKK. Effects of auriculotherapy on labour pain: a randomized clinical trial. Rev Esc Enferm USP. 2016;50(5):726-732. DOI: http://dx.doi. \\ org/10.1590/S0080-623420160000600003
}

\begin{abstract}
* Extracted from preliminary data of the thesis "Efeitos da auriculoterapia no trabalho de parto: ensaio clínico randomizado", Universidade Estadual de Campinas; 2015.

${ }^{1}$ Universidade Estadual de Campinas, Faculdade de Enfermagem, Campinas, SP, Brazil.
\end{abstract}

\begin{abstract}
Objective: Assessing the effects of auriculotherapy in pain control and its outcomes on the duration of labour. Method: This is a randomized, controlled, double-blind trial with preliminary data. Thirty pregnant women with gestational age $\geq 37$ weeks, cervical dilatation $\geq 4 \mathrm{~cm}$ and two or more contractions in 10 minutes were selected and randomly divided into three groups: auriculotherapy, placebo and control. Auriculotherapy was applied using crystal beads on four strategic points. Results: No statistical significance was found between the groups with regard to pain; however, the women from the auriculotherapy group had lower intensity and less perception of pain at 30,60 and 120 minutes of treatment. The average duration of labour was shorter in the auriculotherapy group (248.7 versus placebo 414.8 versus control 296.3 minutes); caesarean section rates were higher in the placebo group (50\%) and the same in the other groups $(10 \%)$. Conclusion: Mothers who received auriculotherapy presented a tendency for greater pain control and shorter labour duration; however, caesarean section rates in this group were similar to the control group. This trial precedes a larger study in progress. Registration of Brazilian Clinical Trials: RBR-47hhbj.
\end{abstract}

\section{DESCRIPTORS}

Auriculotherapy; Labor Pain; Labor, Obstetric; Cesarean Section; Obstetric Nursing. 


\section{INTRODUCTION}

Complementary and alternative therapies (CATs) are encouraged by the World Health Organization (WHO) in its recommendations for the assistance of normal labour and delivery, classifying them as conducts that are clearly useful and should be encouraged ${ }^{(1)}$. In traditional Chinese medicine (TCM), some therapies substitute or are used complementarily to conventional medicinal treatments. Acupuncture, auriculotherapy and acupressure are some examples of TCM therapies. Acupressure uses specific acupuncture points, however it is performed by pressure with fingers or hands without the use of needles ${ }^{(2)}$. A randomized controlled trial $(\mathrm{RCT})^{(3)}$ assessed the effects of acupressure on labour pain and labour duration of 100 labouring women. This study showed a lower pain score on the visual analogue scale (VAS) among the patients who received the therapy ( $p$-value $<0.001)$, as well as a shorter duration of labour (225 minutes for acupressure versus 320 minutes for control group, $p$-value $=0.000$ ) .

In a study of systematic reviews on the use of non-pharmacological methods in pain management during labour, the authors concluded that there was some evidence of efficacy in the use of immersion baths, relaxation, acupuncture and massage, but it did not clarify the effectiveness of other techniques ${ }^{(4)}$. Most CATs in pain management are not invasive and appear safe for mother and baby; however, their efficacy is uncertain due to the quality of the studies ${ }^{(4)}$.

The use of non-pharmacological methods for the treatment of labour pain usually have no side effects and can delay or prevent the use of analgesia or medication, which can increase the frequency of instrumental deliveries and interfere with breast feeding, among other effects ${ }^{(4-5)}$.

Auriculotherapy has been used to treat various disorders and to promote analgesia through the stimulation of reflex points in the auricle ${ }^{(6)}$. This therapy aims to harmonize the functions of organs, viscera and physical and mental illnesses, based on the reflex that the stimulus of such points exerts on the central nervous system from needles and pressure by microspheres and seeds. A multicentric study ${ }^{(7)}$ assessed the effectiveness of auriculotherapy using vaccaria seeds (known in China as Wang Bu Liu Xing) in patients with unspecified back pain in the primary health care system. This study revealed a significant difference when comparing the pain scores of the treatment group versus placebo $(p=$ $0.024)$ and described the technique as safe and effective in this population.

Some studies have assessed the achievements of auriculotherapy in acute pain (hip fracture, biliary colic, burning) and in chronic pain (sore throat, back pain, cancer, temporomandibular joint), as shown by a systematic review using a metaanalysis ${ }^{(8)}$. In perioperative pain, auriculotherapy reduced the use of analgesics, and there was a reduction in the intensity of acute and chronic pain. The same review also reported that auriculotherapy may be effective for the treatment of pain by different causes, especially postoperative pain.

Auriculotherapy has some points described for treating pain and for labour dystocia ${ }^{(6,9)}$. Although there is a lack of studies in the field in literature, it can be an alternative to the enabled care provider, especially in the establishment of non-invasive treatments that contribute to the humanization of birth. In this context, the present study aimed at assessing the effects of this therapy on pain control in the active phase of labour and the evolution of labour.

\section{METHOD}

This is a randomized controlled clinical trial with a pragmatic approach ${ }^{(10)}$ carried out from April 2015 to August 2015, with preliminary data from the study.

\section{PARTICIPANTS}

The study subjects were 30 pregnant women admitted to a public teaching hospital located in the state of São Paulo, Brazil, for labour and delivery care. Women of any age or parity were included, from 37 weeks of gestation in spontaneous, induced and/or conducted labour with dilatation $\geq$ $4 \mathrm{~cm}$, two or more contractions in 10 minutes, with intact skin in the auricle pavilion and a living foetus, showing vertex cephalic presentation and having good vitality conditions. Cases with dilatation $\geq 7 \mathrm{~cm}$, severe preeclampsia, placenta praevia, previous caesarean section or immediate indication for this type of delivery were excluded.

\section{Data collection}

A questionnaire submitted to content validity analysis by five judges with experience in obstetrics and/or in traditional Chinese medicine was elaborated in order to collect sociodemographic and clinical data.

The allocation of pregnant women into the study groups was performed through hidden allocation using sealed and sequentially numbered opaque envelopes, and then opened by the main researcher after including the labouring women in the study. This was accomplished in the presence of two non-participating employees of the unit who did not provide assistance to the women. Three groups were allocated: auriculotherapy with crystal beads (AC); auriculotherapy with glass beads (placebo) which are similar to crystals, however, if they are not manipulated they do not activate auricular points; and control group (CG). The study used the double-blind method; therefore, neither the labouring women from AC, placebo groups, the evaluators, or professionals providing assistance in the obstetrical unit knew which group each participant belonged to. It was not possible to blind participants, evaluators or professionals of the third group to treatment due to the characteristics of the study.

The evaluation team was composed of five employees of the obstetrical unit nursing staff who were instructed about the purposes of this study, previously trained for data collection and the use of VAS. The researcher responsible for applying auriculotherapy underwent technical training in two short courses, totalling 64 hours.

The labouring women were approached in the pre-delivery room (PP) or pre-partum, delivery and postpartum room (PPP), assessed for eligibility, invited to participate in the 
study, and then subsequently allocated through the hidden random selection previously described and accompanied by the team of evaluators until the next day after delivery.

\section{INTERVENTION}

For AC and placebo groups, the following acupuncture points were used according to the Chinese auricular map/ chart: i) shen men, which predisposes the brain stem and cortex to receive, condition and encode the ear reflexes, having sedative, analgesic effects; ii) uterus which is indicated in gynaecological and obstetric alterations, for labour induction or for reducing the expulsive period and for reducing pain in the postpartum period; iii) neurasthenia area, indicated for the treatment of anxiety; iv) endocrine, regulating functions of endogenous secretory glands, being used in gynaecological disorders, among others ${ }^{(6,9)}$.

Auricles were cleaned using rubbing alcohol; the points were identified by pressuring probing points and defined as the most painful pressure points closest to those indicated in the topography of the "Auricular points chart". As the points were located, the crystals were inserted into $\mathrm{AC}$ group and individually pressed for a minute or until causing tolerable pain to induce stimulation. For the placebo group, the points were used to indicate the location for fixing the glass microsphere; however this material had no direct contact with the skin of the parturient, as it was used on the inner side between the glass bead and the determined point, not visible by external fixation. The auricular points were determined as close to the topography indicated on the "points chart" in the placebo group and without pressure stimuli at any time during the study. Women allocated to the CG were accompanied over the same period and assessed by VAS, similar to the other groups.

Humanized care practices were used in the local obstetric unit of this study, such as the women's right to choose a companion during labour and delivery and joint accommodations. The labouring women could also make use of a shower bath, lumbosacral massage, and breathing exercises, an exercise ball and have freedom of movement in the cases where there were no medical contraindications. However, intravenous oxytocin, prostaglandins and amniotomy (artificial rupture of membranes) were routinely used during labour and delivery.

\section{Primary AND SECONDARY OUtComeS}

To evaluate the primary outcome of this RCT (the intensity of the reported labour pain), a VAS developed by the pain control team was used from the anaesthesiology course of the Hospital das Clínicas, Faculty of Medicine of São Paulo $^{(11)}$. The scale is composed of counting down from 10 to 0 , where 10 is equivalent to excruciating pain and 0 to the absence of pain. The VAS was applied at study admission and reapplied at 30,60 and 120 minutes by the evaluating team.

Regarding secondary outcomes (duration of labour, type of delivery and Apgar score), the following data were recorded according to the performed procedures and checked by the team of professionals working at the study site: use of uterotonic agents, analgesics (intravenous and intramuscular) and anaesthesia, type of delivery, time of birth, referring to their medical records, anaesthesia record, partogram and medical prescription.

\section{SAMPLE CALCULATION}

The sample size calculation was performed in order to compare groups in relation to pain intensity variables and labour duration. The proposed methodology for an ANOVA model was considered, since these variables are quantitative and compared among three groups; estimates of the variable averages for each group and standard deviation of the mean square error of the model were based on a previous study $y^{(2)}$ on the effect of acupressure on labour pain and labour duration. In addition, a significance level of 5\% and $80 \%$ power for test sample calculations were assumed. The calculation resulted in a sample of 17 subjects per group for the pain intensity variable, and a sample of 33 subjects per group for the duration of labour variable. The calculation resulted in a total sample of 99 individuals.

\section{Statistical Analysis}

Comparisons among the groups regarding quantitative variables were performed using the Kruskal-Wallis test. Fisher's exact test was applied to evaluate the association among the groups and qualitative variables. The Bonferroni correction was applied in assessing the results of variables with more than one measurement, dividing the significance level of $5 \%$ by the number of assessments. Analyses were performed by the Statistical Analysis System 9.2 (SAS) software, performed by a statistics professional.

\section{ETHICAL ASPECTS}

Women who agreed to participate signed the Clear and Informed Consent Form (ICF). This study was approved by the Research Ethics Committee of the Universidade Estadual de Campinas, São Paulo (Number 855.496).

\section{RESULTS}

Thirty women in labour divided equally into three groups participated in this study. There were no losses after randomization; only labouring women who were submitted to caesarean sections or those whose delivery took place before the (final) pain assessment at 120 minutes were excluded from the analyses of labour duration (from treatment to birth) (Figure 1).

Table 1 presents general and obstetric characteristics of pregnant women, according to the study group. The groups were similar with respect to age and marital status, but the average years of education was higher in the AC group. Most mothers had completed secondary education (80.0\% of the AC group, $100.0 \%$ of placebo and $90.0 \%$ of CG). The others were attending or had completed higher education.

The participating women were asked about their knowledge of auriculotherapy as a complementary treatment for various types of symptoms or diseases. The results showed that $80 \%$ of women in the $\mathrm{AC}$ group and $70 \%$ of those in the placebo and control groups did not know about this therapy. 


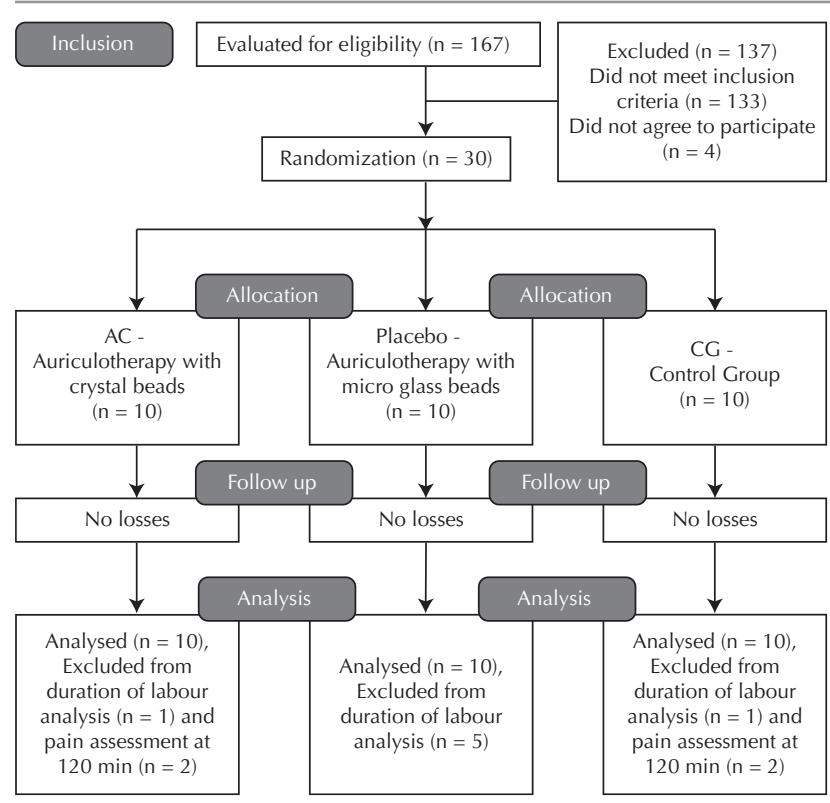

Figure 1 - Data collection flowchart - Campinas, São Paulo, Brazil, 2015.

For obstetric characteristics reported in Table 1, multiparity was higher in the placebo and control group. In turn, induced labour was higher in the placebo group. The other characteristics were similar among the groups upon study admission.

Table 1 - Distribution of labouring women according to study groups and socio-demographic and obstetric characteristics Campinas, São Paulo, Brazil, 2015.

\begin{tabular}{lccc}
\hline \multirow{2}{*}{ Variable } & \multicolumn{3}{c}{ Study group } \\
\cline { 2 - 4 } & $\begin{array}{c}\text { Auriculotherapy } \\
(\mathbf{n}=\mathbf{1 0})\end{array}$ & $\begin{array}{c}\text { Placebo } \\
(\mathbf{n = 1 0})\end{array}$ & $\begin{array}{c}\text { Control } \\
(\mathbf{n}=\mathbf{1 0})\end{array}$ \\
\hline Age (years), average (SD) & $22.2(6.3)$ & $\begin{array}{c}22.8 \\
(5.8)\end{array}$ & $\begin{array}{c}22.9 \\
(4.5)\end{array}$ \\
Marital status, n (\%) & & & \\
$\quad$ With a partner & $8(80.0)$ & $10(100)$ & $9(90.0)$ \\
$\quad$ Without a partner & $2(20.0)$ & $0(0.0)$ & $1(10.0)$ \\
$\begin{array}{l}\text { Education level (years of } \\
\text { education), average (SD) }\end{array}$ & $11.6(4.6)$ & $8.3(2.2)$ & $8.5(3.1)$ \\
$\begin{array}{l}\text { N. of prenatal } \\
\text { Consultations, average (SD) }\end{array}$ & $9.5(2.6)$ & $\begin{array}{c}10.5 \\
(3.0)\end{array}$ & $8.5(3.8)$ \\
$\begin{array}{l}\text { N. of gestations, average } \\
\text { (SD) }\end{array}$ & $1.3(0.7)$ & $1.8(1.2)$ & $2.1(1.6)$ \\
$\begin{array}{l}\text { Parity, n (\%) } \\
\text { Nulliparous }\end{array}$ & & & \\
$\begin{array}{l}\text { Multiparous } \\
\text { Induced labour, n (\%) }\end{array}$ & $3(80.0)$ & $5(50.0)$ & $5(50.0)$ \\
Amniotic membranes, n (\%) & & $5(50.0)$ & $5(50.0)$ \\
$\begin{array}{l}\text { Intact } \\
\text { Artificial rupture of mem- } \\
\text { branes }\end{array}$ & $1(10.0)$ & $2(20.0)$ & $2(20.0)$ \\
\hline
\end{tabular}

continued...

\begin{tabular}{|c|c|c|c|}
\hline \multirow[b]{2}{*}{ Variable } & \multicolumn{3}{|c|}{ Study group } \\
\hline & $\begin{array}{l}\text { Auriculotherapy } \\
\quad(\mathbf{n}=\mathbf{1 0})\end{array}$ & $\begin{array}{l}\text { Placebo } \\
(n=10)\end{array}$ & $\begin{array}{l}\text { Control } \\
(n=10)\end{array}$ \\
\hline $\begin{array}{l}\text { Spontaneous rupture of } \\
\text { membranes }\end{array}$ & $1(10.0)$ & $2(20.0)$ & $2(20.0)$ \\
\hline $\begin{array}{l}\text { Cervical dilatation }(\mathrm{cm}), \\
\text { average }(\mathrm{SD})\end{array}$ & $4.8(0.8)$ & $4.7(0.7)$ & $5.1(0.9)$ \\
\hline $\begin{array}{l}\text { N. of contractions, average } \\
\text { (SD) }\end{array}$ & $3.0(0.8)$ & $3.2(0.8)$ & $3.3(1.1)$ \\
\hline \multicolumn{4}{|l|}{$\begin{array}{l}\text { Intensity of contractions, } \\
\mathrm{n}(\%)\end{array}$} \\
\hline Weak & $0(0.0)$ & $1(10.0)$ & $0(0.0)$ \\
\hline Moderate & $6(60.0)$ & $7(70.0)$ & $6(60.0)$ \\
\hline Strong & $4(40.0)$ & $2(20.0)$ & $4(40.0)$ \\
\hline
\end{tabular}

Table 2 presents the data for the primary outcome of this study, the pain assessment though VAS and the perception of the pregnant women before and after treatment in each group. Losses of labouring women in the $\mathrm{AC}$ and control groups were the result of vaginal delivery occurring prior to the final assessment of pain at 120 minutes.

Epidural or combined spinal-epidural anaesthesia (Spinal anaesthesia + epidural) was available to labouring women depending on their needs; its use was common in the three groups, occurring in $60.0 \%$ in the $\mathrm{AC}$ group, $80.0 \%$ in the placebo group and $50.0 \%$ in the CG. There was no use of intravenous or intramuscular analgesics administered during labour.

Regarding the secondary outcomes (Table 3), labour duration was calculated from the beginning of the rhythmic and painful contractions reported by labouring women until treatment, and from treatment to delivery (birth). There was no statistical difference in relation to the duration of the labour before treatment. The average duration of labour in the AC group was 166, 1 minute less than the placebo group and 47.6 minutes less than the control group after treatment. The selection of pregnant women in the active phase of labour did not interfere with the use of uterotonic agents during delivery, according to obstetrical conduct, which occurred in a higher percentage in the placebo group, followed by $\mathrm{AC}$ and control groups. Caesarean section rates were higher for $\mathrm{CG}$ and equal to $\mathrm{AC}$ group and placebo. The Apgar score (the most used method for immediate assessment of the baby's condition at birth) showed no differences between the averages presented in the first and fifth minutes of life.

Most of the subjects had the presence of a companion throughout their labour and delivery (80.0\%). Only one patient in the placebo group and another in the CG were unaccompanied.

The day after delivery after being questioned about the discomfort caused by the treatment, the $\mathrm{AC}$ and placebo groups showed no statistical difference between them regarding their responses, being categorized as follows: no discomfort (70\% AC versus $80 \%$ placebo), a little discomfort (20\% AC versus $30 \%$ placebo), much discomfort ( $0 \%$ $\mathrm{AC}$ versus $0 \%$ placebo), $p$-value $=1.000$ (Fisher exact test). 
Table 2 - Differences in VAS scores and pain assessment among the study groups - Campinas, São Paulo, Brazil, 2015.

\begin{tabular}{|c|c|c|c|c|c|c|c|}
\hline \multirow{3}{*}{$\begin{array}{l}\text { Variable } \\
\text { VAS }^{*}\end{array}$} & \multicolumn{6}{|c|}{ Study group } & \multirow{3}{*}{$p$-value } \\
\hline & \multicolumn{2}{|c|}{$\begin{array}{l}\text { Auriculotherapy } \\
\quad(\mathbf{n}=10)\end{array}$} & \multicolumn{2}{|c|}{$\begin{array}{l}\text { Placebo } \\
(\mathrm{n}=10)\end{array}$} & \multicolumn{2}{|c|}{$\begin{array}{l}\text { Control } \\
(n=10)\end{array}$} & \\
\hline & Average & SD & Average & SD & Average & SD & \\
\hline Prior to treatment & 7.1 & $(1.4)$ & 6.5 & (2.3) & 7.8 & $(1.8)$ & $0.318^{+}$ \\
\hline At $30 \mathrm{~min} /$ treatment & 6.7 & $(2.1)$ & 6.7 & (2.3) & 8.2 & $(1.8)$ & $0.199^{+}$ \\
\hline At $60 \mathrm{~min} /$ treatment & 6.7 & (1.9) & 7.1 & $(2.2)$ & 8.2 & $(1.7)$ & $0.219^{+}$ \\
\hline At $120 \mathrm{~min} /$ treatment & 5.5 & $(3.5)$ & 7.9 & $(2.0)$ & 7.9 & $(3.8)$ & $0.271^{+}$ \\
\hline Perception of pain (30 min) & $\mathbf{n}$ & $\%$ & $\mathbf{n}$ & $\%$ & $\mathbf{n}$ & $\%$ & \\
\hline Better & 3 & $(30.0)$ & 1 & $(10.0)$ & 0 & $(0.0)$ & \\
\hline Same & 6 & $(60.0)$ & 7 & $(70.0)$ & 6 & $(60.0)$ & $0.311^{\ddagger}$ \\
\hline Worse & 1 & $(10.0)$ & 2 & $(20.0)$ & 4 & $(40.0)$ & \\
\hline Perception of pain (60 min) & $\mathbf{n}$ & $\%$ & $\mathbf{n}$ & $\%$ & $\mathbf{n}$ & $\%$ & \\
\hline Better & 3 & $(30.0)$ & 1 & $(10.0)$ & 3 & $(30.0)$ & \\
\hline Same & 5 & $(50.0)$ & 3 & $(30.0)$ & 5 & $(50.0)$ & $0.462^{\ddagger}$ \\
\hline Worse & 2 & $(20.0)$ & 6 & $(60.0)$ & 2 & $(20.0)$ & \\
\hline Perception of pain (120 min) & $\mathbf{n}$ & $\%$ & $\mathbf{n}$ & $\%$ & $\mathbf{n}$ & $\%$ & \\
\hline Better & 2 & $(25.0)$ & 0 & $(0.0)$ & 0 & $(0.0)$ & \\
\hline Same & 4 & $(50.0)$ & 3 & $(30.0)$ & 3 & $(37.5)$ & $0.192^{\ddagger}$ \\
\hline Worse & 2 & $(25.0)$ & 7 & $(70.0)$ & 5 & $(62.5)$ & \\
\hline Not reported (losses) & 2 & & 0 & & 2 & & \\
\hline
\end{tabular}

Visual Analogue Scale. ${ }^{\dagger}$ Kruskal-Wallis test, $p$-value $<0.0125 .{ }^{\ddagger}$ Fisher Exact test, $p$-value $<0.167$.

Table 3 - Distribution of labouring women according to the study groups and variables related to childbirth - Campinas, São Paulo, Brazil, 2015.

\begin{tabular}{|c|c|c|c|c|c|c|c|}
\hline \multirow{3}{*}{$\begin{array}{l}\text { Variable } \\
\text { Labour duration (min) }\end{array}$} & \multicolumn{6}{|c|}{ Study group } & \multirow{3}{*}{$p$-value } \\
\hline & \multicolumn{2}{|c|}{$\begin{array}{l}\text { Auriculotherapy } \\
\qquad(\mathbf{n}=10)\end{array}$} & \multicolumn{2}{|c|}{$\begin{array}{l}\text { Placebo } \\
(n=10)\end{array}$} & \multicolumn{2}{|c|}{$\begin{array}{l}\text { Control } \\
(n=10)\end{array}$} & \\
\hline & Average & SD & Average & SD & Average & SD & \\
\hline Until treatment & 332.0 & (141.9) & 453.2 & $(370.6)$ & 410.0 & $(270.7)$ & $0.951^{*}$ \\
\hline From treatment to birth & 248.7 & $(98.8)$ & 414.8 & $(319.3)$ & 296.3 & $(187.3)$ & - \\
\hline Induction of labour & $\mathbf{n}$ & $\%$ & $\mathbf{n}$ & $\%$ & $\mathbf{n}$ & $\%$ & - \\
\hline Prostaglandin & 3 & $(30.0)$ & 3 & $(30.0)$ & 3 & $(30.0)$ & - \\
\hline Oxytocin & 4 & $(40.0)$ & 7 & $(70.0)$ & 2 & $(20.0)$ & - \\
\hline Type of delivery & $\mathbf{n}$ & $\%$ & $\mathbf{n}$ & $\%$ & $\mathbf{n}$ & $\%$ & \\
\hline Vaginal & 9 & $(90.0)$ & 5 & $(50.0)$ & 9 & $(90.0)$ & - \\
\hline Caesarean & 1 & $(10.0)$ & 5 & $(50.0)$ & 1 & $(10.0)$ & - \\
\hline Apgar scores & Average & SD & Average & SD & Average & SD & \\
\hline $1^{\text {st }}$ minute & 9.4 & $(0.5)$ & 8.1 & (1.8) & 8.2 & (2.9) & $0.123 *$ \\
\hline $5^{\text {th }}$ minute & 9.8 & (0.4) & 9.7 & (0.5) & 9.1 & (2.9) & $0.636^{*}$ \\
\hline
\end{tabular}

"Kruskal-Wallis test, $p$-value $<0.0125$.

\section{DISCUSSION}

This study sought to evaluate the effects of auriculotherapy on pain control and in the evolution of labour in a population mostly unfamiliar with this type of treatment, indication and purpose. The results showed lower pain scores between the patients who received the therapy; however, there was no difference between the groups in terms of duration and type of delivery. The education level was higher than average in the AC group; in the other groups, the average was close to official statistics (8.1 years of education) for women in the southeast of $\mathrm{Brazi}^{(12)}$ (the collection site).

Although there were no differences between the groups with respect to pain scores, the perception of increased pain during contractions was higher in the placebo and control groups, which may show a beneficial effect of auriculotherapy 
treatment. An Iranian study ${ }^{(9)}$ also evaluated the effects of auriculotherapy on pain of 80 nulliparous women in active delivery phase by VAS and showed statistically significant results by comparing groups (7.56 auriculotherapy versus 8.43 CG, $p<0.05)$. In this context, a larger sample size in this study could verify the effectiveness of auriculotherapy in relieving pain during labour. The use of analgesia in delivery occurred frequently in the three groups, as it is a common practice in the obstetrical unit.

Another $\mathrm{RCT}^{(13)}$ with 207 women compared the use of auriculotherapy with usual treatment (local anaesthetic) for episiotomy repair and perineal lacerations on pain control. In this study, pain during the surgical procedure was more frequent among women allocated into the auriculotherapy group ( $89 \%$ versus $54 \%, p<0.01$ ). The intensity of pain measured through VAS during the repair was also higher $(3.5$ versus $1.5, p<0.01$ ).

Labouring women in the placebo group were the ones who most received an intervention for induced labour. However, the average duration of labour was higher than those in the $\mathrm{AC}$ group. In $\mathrm{CG}$, these interventions were lower after admission; still, the duration of labour was lower in the placebo group; and compared to the AC group, the duration was higher, however the different types of labour induction in these groups may have influenced these values. Two Asian RCT showed shorter durations of labour among the patients who received acupressure ${ }^{(14-15)}$. The average duration of labour was 52.4 minutes $^{(14)}$ and 52.6 minutes $^{(15)}$ less in the acupressure group compared to placebo group, respectively. A Cochrane review ${ }^{(16)}$ on acupuncture for labour induction found few studies that assessed this outcome, and only one RCT included showed significant results: average/ standard deviation (AD) of $0.67,95 \%$ confidence interval (CI) of 0.18 to 1.17 . However, no studies were found in the literature that evaluated the effects of auricular acupuncture or auriculotherapy on the duration of labour.

The type of delivery in this RCT was similar for AC and control groups. For the placebo group, caesarean rates were higher which occurred in 50\% of births, being slightly higher than those registered in the first half 2014 on the collection site $(43.8 \% \text { of caesareans })^{(17)}$. In a case study ${ }^{(18)}$, six pregnant women with prior abdominal transverse surgical scar were treated with auriculotherapy to evaluate type of delivery. The authors reported that auriculotherapy can reduce conditions involving obstructed labour and possibly reduce caesarean rates, which occurred in only one participant. In another study ${ }^{(19)}$, there was no statistical difference, the caesarean rate was $8.3 \%$ in the group with acupuncture and $8.7 \%$ in the usual treatment $(p=0.418)$. There were no differences in the Apgar score, indicating that the type of treatment for each group did not change this indicator in this study.

The integral presence of a companion of the mother's choosing was a predominant characteristic in the groups, which contributes to safety and less trauma confrontation for women during this process. Continuous support for women during childbirth brings clinical benefits and may favour the evolution of birth, as shown by another Cochrane review ${ }^{(20)}$.

Limitations of this study include the small sample size, which prevented the application of statistical tests for some variables. It was not possible to identify the total dose of oxytocin and prostaglandins administered (mainly due to the absence of exact dosage in some medical records of the unit). Therefore, only the number of participants who received these drugs in the three groups was described. The study was conducted in a university hospital which is a regional reference for high-risk pregnancy and where the practice of interventions during labour and delivery is common. This study contributed to knowledge of research organization and application of auricular therapy, and will be used by the main investigator and the team of evaluators in the final phase of data collection.

Women from the auriculotherapy group demonstrated greater control of pain in the VAS, however there were no differences between the study groups. Considering that labour pain increases progressively, the fact that no reports of increased pain were reported demonstrates a favourable effect of the intervention. Regarding the secondary outcomes evaluated after delivery, there was a trend of shorter labour duration in the AC group after treatment; however, there is no way to say whether it was related to auriculotherapy. This is also true for the type of delivery between the groups. This RCT will continue until completion of the estimated sample size in order to obtain clearer results regarding the effectiveness of this treatment on the variables in order to present new alternative or complementary non-invasive therapies that can generate greater satisfaction for women during childbirth.

\section{CONCLUSION}

In this study, women undergoing auriculotherapy during labour did not show different pain scores or duration of labour from the placebo or control groups. However, their results suggest the need for studies with larger sample sizes, and preferably conducted in environments where practices that result in increased pain in childbirth, such as amniotomy and oxytocin, are not routinely used.

\section{RESUMO}

Objetivo: Avaliar os efeitos da auriculoterapia no controle da dor e seus desfechos na duração do trabalho de parto. Método: Trata-se de um ensaio controlado, randomizado e duplo-cego, com dados preliminares. Foram selecionadas 30 parturientes com idade gestacional $\geq$ 37 semanas, dilatação cervical $\geq 4 \mathrm{~cm}$ e duas ou mais contrações em 10 minutos, divididas aleatoriamente em três grupos: auriculoterapia, placebo ou controle. A auriculoterapia foi aplicada com microesferas de cristais em quatro pontos estratégicos. Resultados: Não houve significância estatística entre os grupos com relação à dor; no entanto, as mulheres do grupo de auriculoterapia, apresentaram menor intensidade e menor percepção da dor aos 30,60 e 120 minutos do tratamento. A média de duração do trabalho de parto foi menor no grupo de auriculoterapia ( 248,7 versus placebo 414,8 versus controle 296,3 minutos); a taxa de cesárea foi maior no grupo placebo (50\%) e igual nos outros (10\%). Conclusão: As parturientes que receberam auriculoterapia apresentaram tendência a um maior controle da 
dor e menor duração do trabalho de parto, porém a taxa de cesárea neste grupo foi semelhante à do grupo controle. Este ensaio precede um estudo maior, em andamento. Registro Brasileiro de Ensaio Clínico: RBR-47hhbj.

\section{DESCRITORES}

Auriculoterapia; Dor do Parto; Trabalho de Parto; Cesárea; Enfermagem Obstétrica.

\section{RESUMEN}

Objetivo: Evaluar los efectos de la auriculoterapia en el control del dolor y sus resultados en la duración del trabajo de parto. Método: Se trata de un ensayo controlado, aleatorizado y doble ciego, con datos preliminares. Fueron seleccionadas 30 parturientes con edad gestacional $\geq 37$ semanas, dilatación cervical $\geq 4 \mathrm{~cm}$ y dos o más contracciones en 10 minutos, divididas aleatoriamente en tres grupos: auriculoterapia, placebo o control. La auriculoterapia se aplicó con microesferas de cristales en cuatro puntos estratégicos. Resultados: No hubo significación estadística entre los grupos con relación al dolor; sin embargo, las mujeres del grupo de auriculoterapia presentaron menor intensidad y menor percepción del dolor a los 30,60 y 120 minutos del tratamiento. El promedio de duración del trabajo de parto fue menor en el grupo de auriculoterapia (248,7 versus placebo 414,8 versus control 296,3 minutos); la tasa de cesárea fue mayor en el grupo placebo $(50 \%)$ y igual en los otros (10\%). Conclusión: Las parturientes que recibieron auriculoterapia presentaron tendencia a un mayor control del dolor y menor duración del trabajo de parto, pero la tasa de cesárea en ese grupo fue semejante a la del grupo control. Este ensayo precede un estudio mayor, en curso. Registro Brasileño de Ensayo Clínico: RBR-47hhbj.

\section{DESCRIPTORES}

Auriculoterapia; Dolor de Parto; Trabajo de Parto; Cesárea; Enfermería Obstétrica.

\section{REFERENCES}

1. World Health Organization; Reproductive Health and Research. Care in normal birth: a practical guide. Report of a Technical Working Group. Geneva: WHO; 1996.

2. Mafetoni RR, Shimo AKK. Effects of acupressure on progress of labor and cesarean section rate: randomized clinical trial. Rev Saúde Pública. 2015;49:9.

3. Yesilcicek CK, Komurcu N. Effects of SP6 acupuncture point stimulation on labor pain and duration of labor. Iran Red Crescent Med J. 2014;16(10):e16461.

4. Jones L, Othman M, Dowswell T, Alfirevic Z, Portas S, Newburn M, et al. Pain management for women in labour: an overview of systematic reviews. Cochrane Database Syst Rev. 2012;(3):CD009234.

5. Moghimi-Hanjani S, Mehdizadeh-Tourzani Z, Shoghi M. The effect of foot reflexology on anxiety, pain, and outcomes of the labor in primigravida women. Acta Med Iran. 2015;53(8):507-11.

6. Nogier R, Boucinhas JC. Prática fácil de auriculoterapia e auriculomedicina. $4^{\mathrm{a}}$ ed. São Paulo: Ícone; 2012.

7. Vas J, Modesto M, Aguilar I, Gonçalo CS, Rivas-Ruiz F. Efficacy and safety of auriculopressure for primary care patients with chronic nonspecific spinal pain: a multicentre randomised controlled trial. Acupunct Med. 2014;32(3):227-35.

8. Asher GN, Jonas DE, Coeytaux RR, Reilly AC, Loh YL, Motsinger-Reif AA, et al. Auriculotherapy for pain management: a systematic review and meta-analysis of randomized controlled trials. J Altern Complement Med. 2010;16(10):1097-108.

9. Rastegarzade H, Abedi P, Valiani M, Haghighi MH. The effect of auriculotherapy on labor pain intensity in nulliparous women (persian). J Anesthesiol Pain. 2015;6(1):54-63.

10. Schwartz D, Lellouch J. Explanatory and pragmatic attitudes in therapeutical trials. J Clin Epidemiol. 2009;62(5):499-505.

11. Pereira LV, Sousa FAEF. Mensuração e avaliação da dor pós-operatória, uma breve revisão. Rev Latino Am Enfermagem. 1998;6(3):77-84.

12. Instituto Brasileiro de Geografia e Estatística; Diretoria de Pesquisas, Coordenação de Trabalho e Rendimento. Pesquisa Nacional por Amostra de Domicílios - PNAD 2011 [Internet]. Rio de Janeiro: IBGE; 2012 [citado 2016 jan. 15]. Disponível em: http://www.ibge.gov. br/home/presidencia/noticias/imprensa/ppts/00000010135709212012572220530659.pdf

13. Kindberg S, Klünder L, Strom J, Henriksen TB. Ear acupuncture or local anaesthetics as pain relief during postpartum surgical repair: a randomized controlled trial. BJOG. 2009;116(4):569-76.

14. Lee MK. Effects of San-Yin-Jiao (SP6) acupressure on labor pain, delivery time in women during labor [abstract]. Taehan Kanho Hakhoe Chi. 2003;33(6):753-61.

15. Lee MK, Chang SB, Kang D. Effects of San-Yin-Jiao(SP6) acupressure on labor pain, delivery time in women during labor. J Altern Complement Med. 2004;10(6):959-65.

16. Smith CA, Collins CT, Crowther CA, Levett KM. Acupuncture or acupressure for pain management in labour. Cochrane Database Syst Rev. 2011;(7):CD009232.

17. Universidade Estadual de Campinas; Hospital da Mulher Prof. Dr. José Aristodemo Pinotti, Centro de Atenção Integral à Saúde da Mulher. Relatório Semestral de Atividades do Conselho Técnico Administrativo - CTA/CAISM [Internet]. Campinas; 2014 [citado 2016 jan. 15]. Disponível em: http://www.caism.unicamp.br/templates/shaper_pheonix/PDF/Relatorio_Atividades_1Semestre_2014.pdf

18. Greenwood M, Richardson LL. The use of ear acupuncture to promote vaginal delivery after previous cesarean-section. Am J Acupuncture. 1992;20(4):305-12.

19. Borup L, Wurlitzer W, Hedegaard M, Kesmodel US, Hvidman L. Acupuncture as pain relief during delivery: a randomized controlled trial. Birth. 2009;36(1):5-12.

20. Hodnett ED, Gates S, Hofmeyr GJ, Sakala C. Weston J. Continuous support for women during childbirth. Cochrane Database Syst Rev. 2011;(2):CD003766. 